\title{
Capital conception of estimating the impact of sport activity of the population
}

\author{
Timur Kramin ${ }^{1, *}$, Marsel Miftakhov², and Dmitry Manushin ${ }^{1}$ \\ ${ }^{1}$ Kazan Innovative University named after V.G. Timiryasov (IEML), Kazan, Russia \\ ${ }^{2}$ State Council (Parliament) of the Republic of Tatarstan, Volga Region University of \\ Sports and Tourism, Kazan, Russia
}

\begin{abstract}
The article presents a new capital conception of estimating the impact of sport activity of the population on the social-economic development of the economy and the society. The social-economic effects of sport activity are estimated through the formation of various types of capital - physical, social, and intellectual, which can be further quantitatively assessed. It was shown that sport activity forms all the above types of capital. The account of all these types of capital allows comprehensive assessment of the effect of the measures aimed at increasing the sport activity of the population. The main applied result of the article is the scientific substantiation of the possibility to assess the recoupment of the investments into physical culture and sports development and the increase of the sport activity of the population. Thus, a new tool for estimating the efficiency of the regional policy in the sphere of physical culture and sports is proposed.
\end{abstract}

\section{Introduction}

Sport activity has a multisided effect on economy and the society in general. The direct impact of sport activity on the production of goods and services in the sectors accompanying sport characterizes the direct effects of sport activity. Such effects include, in particular, the contribution to the added value as a result of the increased demand for goods and services in the sport sphere and the accompanying sectors and the creation of additional employment.

The indirect economic advantages of sport are improved health, reduced healthcare costs and increased labor productivity in people who do sports. These advantages are important not only for an individual but for the economy as a whole.

The social capital, with trust in the society, social links and shared norms and values as its key elements, is largely formed as a result of doing physical training and sports. Below we present the characteristics of the specific impact factors of sport activity and their indicators.

\footnotetext{
${ }^{*}$ Corresponding author: $\underline{\text { Kramin@ } @ \text { ieml.ru }}$
} 
Many researchers substantiated the role of sport activity in the education of youth [1-5]. The development of sport tourism was studied by H. J. Gibson [6, 7] and C. Pigeassou [8]. The economic effects of sport and sport activity were researched by E. V. Zarova and I. V. Solntsev [9], C. Gratton and P. Taylor [10], M. Leeds and P. von Allmen [11], as well as by the authors of the Final Report "Study on the Contribution of Sport to Economic Growth and Employment in the EU", commissioned by the Directorate-General Education and Culture of the European Commission in November 2012 [12].

Also, we consider the previous research substantiating the impact of sport activity on the creation of social capital.

E. Uslaner [13] presented one of the few significant studies on interconnection between sport and social capital. The researcher asserts that the sports sphere forms social capital by enhancing interactions, forming values and respecting the rules.

M. Warren [14] highlights trust, reciprocity and recognition as attributes of sport activity; these are very close by nature to the social capital as interpreted by R. Putnam [15].

Thus, E. Uslaner and M. Warren [14] are unanimous in the opinion that sport entities are well prepared for creating social capital. In particular, M. Warren asserts that the social capital created as a result of participating in sport entities is most topical aspect for forming more general social liabilities (for instance, general trust).

E. Uslaner [13] marks that participation in sport activity forms various social competences which are essentially close to social capital and are bound to have positive social consequences.

The results of a discussion on the importance of sport activity for forming social capital are shown in Table 1.

Table 1. Attributes of sport activity which create the social capital.

\begin{tabular}{|c|c|}
\hline Attributes of sport activity which create the social capital & Source of information \\
\hline \multicolumn{2}{|l|}{ Positive effects of sport activity } \\
\hline $\begin{array}{c}\text { Sport activity enhances autonomy, self-control, resolution, } \\
\text { responsibility, unity of views }\end{array}$ & Papp and Prisztoka, 1995 [16] \\
\hline $\begin{array}{l}\text { Sport teaches, forms a personality, unites, appeases the nervous } \\
\text { system, ennobles }\end{array}$ & Gough, 1997 [17] \\
\hline Forming charac & $\begin{array}{c}\text { Elias, } 1971 \text { [18]; Mandell, } \\
1984 \text { [19] } \\
\end{array}$ \\
\hline $\begin{array}{l}\text { Forming the } \mathrm{k} \\
\text { exchange, imp }\end{array}$ & $\begin{array}{c}\text { Levi, } 1996 \text { [20]; Stolle, 2001, } \\
2003 \text { [21. 22]; Johnson, } 2003 \\
\text { [23]; Seippel, } 2006 \text { [24]; Lin } \\
\text { 2001 [25] } \\
\end{array}$ \\
\hline \multicolumn{2}{|c|}{ Possible negative effects of sport activity from the viewpoint of the social capital creation } \\
\hline $\begin{array}{c}\text { Orientation towards commercialization, competitive success, } \\
\text { professionalism }\end{array}$ & $\begin{array}{c}\text { Hargreaves, } 1986 \text { [26]; } \\
\text { Lasch, } 1991 \text { [27]; Gruneau, } \\
1993 \text { [28]; Morgan, } 1994 \text { [29] }\end{array}$ \\
\hline Nationalism, chauvinism, racism an & $\begin{array}{l}\text { Tännsjö and Tamburrini, } \\
2000[30]\end{array}$ \\
\hline
\end{tabular}

The receding effect of sport activity on the crime rate at various levels was substantiated in the works by M. Cameron and C. J. MacDougall [31], G. Nichols [32], D. Ekholm [33], etc.

Systematization and discussion of the impact factors of sport sector on social-economic development are presented in works $[34,35]$.

Thus, there are a number of publications characterizing the multi-aspect impact of sport activity on the functioning of social-economic systems, including tangible and intangible 
factors. This impact can be embodied in the form of creating various types of capital: physical, social, and intellectual.

\section{Methodology of research}

The review of scientific literature determined a number of tangible and intangible factors of the influence of sport activity on social-economic development of social-economic systems. Russian regions are also social-economic systems of meso-level. Thus, the obtained results completely correspond to the Russian regions.

To simplify the presentation of the social-economic effects of sport activity, all factors are grouped by the types of the created capital, as shown in Fig. 1.

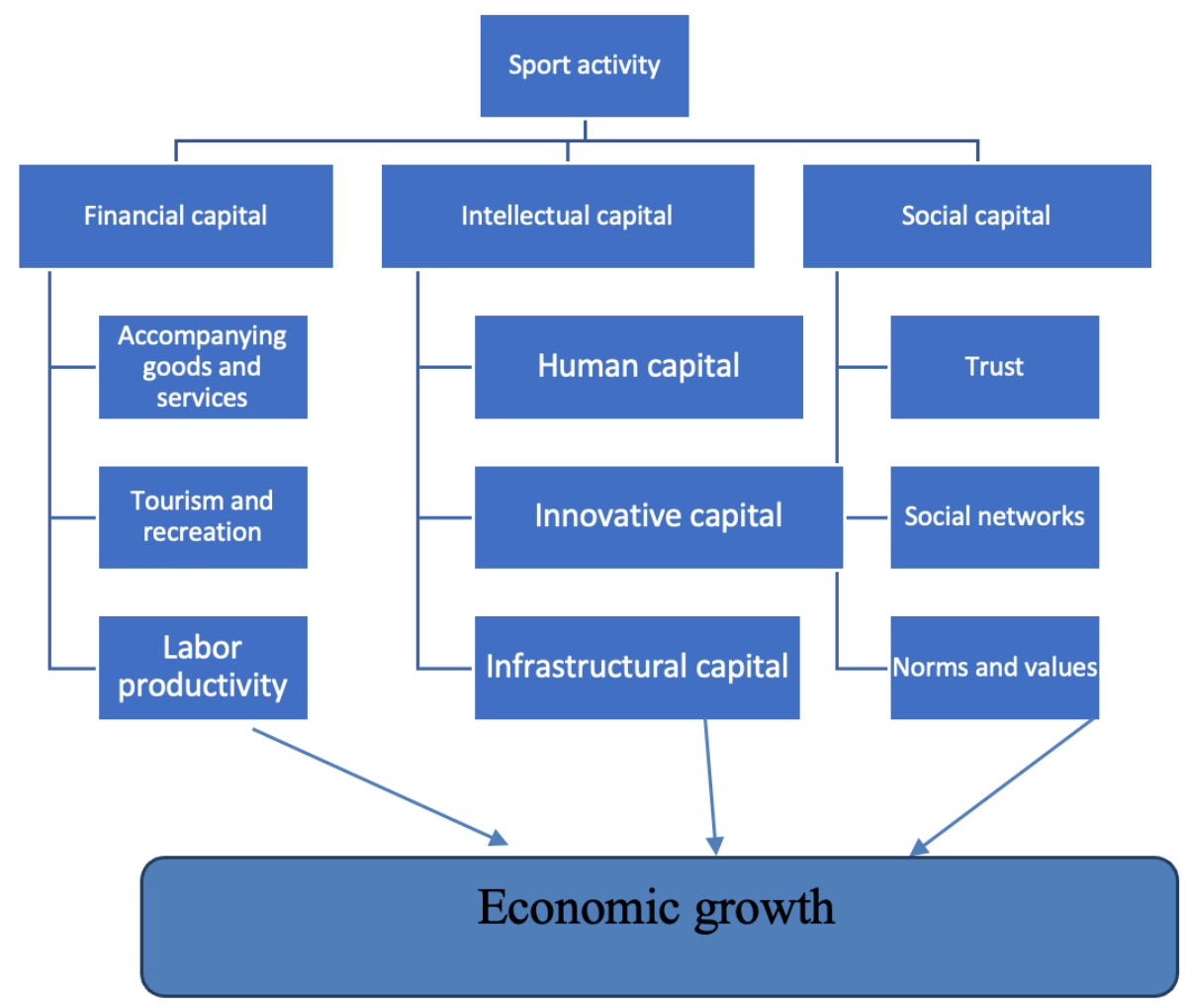

Fig. 1. Channels of influence of sport activity on social-economic development of the Russian regions in the context of capital creation (tangible and intangible assets).

The methodology of representing the effects of sport activity in the form of a systematized group of the created types of capital has the following advantages:

1) the methodology of assessing the above types of capital has been profoundly elaborated in the literature;

2) the aggregate review of all the above types of capital allows the most comprehensive account of the multisided influence of sport activity. 


\section{Research results: revelation, substantiation and analysis of the main channels of impact of sport activity of the population on the economic development of a country and region}

The share of sport sectors in the European GDP is comparable with the shares of agriculture, forestry and fishing taken together. It is almost 2.5 times higher than the corresponding value of mineral extraction and constitutes not less than $20 \%$ of the share of financial services [13].

Activation of all processes associated with sport is, undoubtedly, one of the innovative processes of the recent years. This stems from the analysis of the materials presented in mass media. However, more and more questions arise concerning how the conditions can be created to maintain sport activity in the country and in the regions, as well as in the society at the local and global levels.

In this work, special attention is paid to non-economic areas of influence of doing sports, including education, culture, social sphere, recreation and tourism.

Thus, from the viewpoint of sustainable management, one should consider the possibility and necessity to invest into this multifunctional and multidimensional resource.

Sport sector and tourism are often linked with each other, as these sectors are both associated with the sphere of recreation and leisure. Today, sport is often viewed as an entertainment; from this viewpoint sport events are studied as a public attraction. There is competition between territories for hosting sport events in order to attract tourists and gain economic benefits. In the recent years, one may speak of a special type of tourism - sport tourism, which becomes a specialty of cities, restaurants, hostels, hotels and other facilities equipped to satisfy this new demand of the consumers - tourists.

Today, sport tourism is not officially defined by the UNWTO (United Nations World Tourism Organization); actually it is still included into the "Vacation, recreation and leisure" category.

There are three basic definitions of sport tourism:

- organized or incidental participation in sports activities for non-commercial or commercial reasons which requires leaving home or work [36];

- vacation based on travelling, which temporarily withdraws people out of their residential community with a view of participating in sports events, either as spectators of sports events or as participants of sports entertainment [37, 38];

- gaining touristic and cultural experience in the sphere of sport [39].

In particular, the turnover in the sport tourism market has significantly increased globally in the recent decade. What used to be defined as a mere niche has now become a true segment, growing at a fast rate. Despite a severe economic crisis, this sector has grown. Actually, the annually turnover is estimated as eleven-figure euro and, as it appears, every fourth person chooses a place for vacation taking into account sport offers. Besides, compared to traditional types of tourism, sport tourism ensures correction of seasonality, which begets advantages associated with increased production in all types of activity: hotels, restaurants, and shops of the city [40].

Essentially, sport tourism has a great potential for the development of not only economic but also social and cultural spheres of tourism. In this regard, it is necessary to stimulate a constant and regular cooperation between all stakeholders: sport clubs and associations, public and private organizations, etc. The system created as a result will facilitate the positive economic effects and improve the territory image [40].

Currently, sport activity of the population is being stirred, both as direct engagement in physical activity (on competitive basis or without such), and as observing sports competitions. 
In Europe, over $60 \%$ of the population are engaged in sport activity. For example, in Italy, almost 40 million people do physical culture and sport [13,41].

A number of researchers $[42,43]$ mark that large sport events and spheres of activity have a special social impact, as they:

- change the living style and consumption of families,

- touch upon the social groups which had not been involved in sport (the disabled, women, the elderly),

- emphasize health improvement and body care,

- promote the principles of fair play, solidarity, respect of human rights,

- facilitate the creation of sport associations, unions, volunteer movement.

In the course of time, sport becomes more and more important as a tool of education and training. In Europe, the social and educational spheres of sports development started to appear in official documents not earlier than in the late 1990-s, as the need to regulate the laws on sport in economic sphere became much more obvious - sports sector involved over 15 million people and its overall contribution to employment in EU is 5.8\% [41].

The modern educational models substantiate the need to form a harmonious personality, the development of which requires comprehensive individual training in the spiritual, intellectual, physical, emotional, and social spheres. The universities Great Britain and the USA, for instance, solve this task by organizing involvement into physical culture and sports [44-47].

Sport activity is a plentiful source of information for a person of any age.

That is why physical culture and sports must be integrated into all curricula: from Arts to Natural Sciences, with a view of forming a harmonious personality and civic stand of a learner.

Sport forms a system of values compatible with the values of educational system: for example, personality growth, dialectics of a personality and a group in a team, interaction in a collective and the society, which has its own rules and which should be learned and applied in future, a sense of belonging to a community (see Table 2).

Table 2. Norms and values formed in sport (polling data), $\%$.

\begin{tabular}{|c|c|c|c|c|c|}
\hline \multirow{2}{*}{ Values and norms } & \multicolumn{5}{|c|}{ Age groups (years) } \\
\cline { 2 - 6 } & $18-29$ & $30-44$ & $45-64$ & $>65$ & Average \\
\hline Team spirit & 40.8 & 38.3 & 28.3 & 36.0 & 35.0 \\
\hline Increase of education level & 33.6 & 33.0 & 30.8 & 42.9 & 34.5 \\
\hline Respecting the rules & 24.0 & 33.5 & 27.5 & 31.7 & 29.6 \\
\hline Respecting others & 29.6 & 25.2 & 27.5 & 24.8 & 26.6 \\
\hline Friendship & 29.6 & 22.2 & 25.9 & 24.8 & 25.2 \\
\hline Self-control & 21.6 & 22.6 & 25.5 & 16.8 & 22.1 \\
\hline Tolerance & 15.2 & 17.0 & 21.9 & 14.9 & 17.8 \\
\hline Fair play & 13.6 & 11.7 & 11.7 & 11.2 & 11.9 \\
\hline Solidarity & 10.4 & 12.2 & 10.5 & 9.3 & 10.7 \\
\hline Joy in living & 7.2 & 8.7 & 11.3 & 9.3 & 9.4 \\
\hline Will power & 2.4 & 11.3 & 10.9 & 8.7 & 9.2 \\
\hline Equality & 4.0 & 7.0 & 5.7 & 3.1 & 5.2 \\
\hline Honesty & 3.2 & 3.9 & 2.0 & 8.1 & 4.1 \\
\hline Power & 4.8 & 3.9 & 4.5 & 1.9 & 3.8 \\
\hline Mutual understanding & 7.2 & 3.9 & 2.4 & 2.5 & 3.7 \\
\hline
\end{tabular}

Note. Updated results of the Censis Services Analysis (2007) [48]. Table 2 shows the shares of the respondents who marked the fact of forming the above norms and values in the course of sport 
activity. The total sum of the shares in columns is not equal to 100 as the questionnaire implied the possibility of selecting several answers.

The work [49] reviews and updates the results of a poll "Censis Services Analysis", carried out several years ago, in regard of the key values formed in sport compared to a sample of other types of activity. According to Table 2, the poll was carried out by age groups.

In sport, one cannot do a traditional routine work. An athlete must constantly search for new forms of development of their physical abilities. During their performances, athletes strive to reach the limits of their capabilities, including on the basis of their emotional and spiritual aspects [50-52]. Thus, athletes implement the key educational function - search for solutions and answers to the questions posed by the surrounding world.

Contemporary education also requires going beyond the limits of the existing knowledge, moving forward, going beyond what is innate, creating new opportunities, creating a new person. School kinds of sport may serve as an example for a classical school in this sphere $[53,54]$.

Thus, sport training and intellectual education use the same methods [55]. For a child, a family is an environment differentiated by the age, rank and status of each member, while at school a child stays in a group of peers headed by an adult. Too often, this group of peers is a combination of items which do not form a group with its own life, dynamics, structure and evolution; thus, a school is not capable of fulfilling the role of socialization, which should provide comprehensive education. Sport, especially team kinds of sport, is one of the effective forms of such socialization: each one must play their role, their position and function, which is available to anyone; an individual acts in relation to others; they act, functionally supplementing each other, and their personal values are linked with common values. As a result, conviction is formed that personality growth is an element of the group development and should serve to achieve the goals of the community to which the individual belongs. Thus, sport serves to achieve one of the key goals of education development of a personality in their individual and social constituents, creation of a citizen with personal values and spirituality, which would be put at the service of the society. This is the educational value of sport [56].

On the other hand, doing sports must comply with a number of rules which must be known, studied, and applied. The practice of a team sport implies respecting the rules of game, organizing he behavior of oneself and the team within this institutional structure with the known boundaries; it is necessary to study all the opportunities to learn where one's personal freedom starts and finishes. Thus, in the educational perspective, sport enhances understanding the necessity of rules for various types of social activity of a person and the importance of accepting these rules to learn and know how to apply and use these rules [56].

Through sport, new forms of relations, exchange and dialogue are established. Actually, today the overall formation of a human being, development of their inner world, formation of their potential and competences implies physical education and sports to be comprehensively included into education [57].

Thus, sport activity lays the foundation for developing social institutions and forming an effective institutional environment, necessary for every advanced country including Russia.

Forming a harmonious personality as a result of sport activity is the key channel of sports influence on the socio-economic systems development. The grouping of the norms and values formed in sport by the key dimensions of a harmonious personality is shown in Table 3. 
Table 3. Grouping of the norms and values formed in sport by the key dimensions of a harmonious personality.

\begin{tabular}{|c|c|}
\hline $\begin{array}{c}\text { Dimensions of a harmonious } \\
\text { personality }\end{array}$ & Values and norms of sport \\
\hline Spirituality & $\begin{array}{c}\text { Team spirit, respecting the rules, respecting others, } \\
\text { self-control, tolerance, solidarity, will power, } \\
\text { equality, honesty }\end{array}$ \\
\hline Intellect & Increase of education level \\
\hline Physical health & Healthy lifestyle, physical power, will power \\
\hline Emotional intellect & $\begin{array}{c}\text { Joy in living, mutual understanding, tolerance, } \\
\text { respecting others }\end{array}$ \\
\hline
\end{tabular}

The prerequisites of forming the social, human and innovative capital as a result of sport activity are shown in Table 4 .

Table 4. Grouping of the norms and values formed in sport by the types of capital created (meso- and macroeconomic levels).

\begin{tabular}{|c|c|}
\hline $\begin{array}{c}\text { Social-economic effects of } \\
\text { sport }\end{array}$ & Values and norms of sport which create capital \\
\hline Social capital & $\begin{array}{c}\text { Team spirit, respecting the rules, respecting others, friendship, } \\
\text { self-control, tolerance, solidarity, equality, honesty, mutual } \\
\text { understanding }\end{array}$ \\
\hline Human capital & Healthy lifestyle, increase of education level, will power \\
\hline Innovative capital & Will power, striving for the new horizons \\
\hline
\end{tabular}

\section{Discussion of the results}

The results presented in the review and obtained in the present research allow asserting that it is rather effective and promising to apply the so-called capital conception of estimating the influence of physical culture and sports on the development of economic systems and territories. It was shown that sport activity forms all the above types of capital. Account of all types of capital enables to comprehensively assess the return of the events aimed at increasing sport activity. Hence, it becomes possible to assess the return of investments into physical culture and sports and to increase the level of sport activity, on the basis of scientifically substantiated approaches.

\section{Conclusion}

We may conclude that sport activity has a comprehensive multidimensional effect on the society development and facilitates its socio-economic development. Physical culture and sports are effective tools providing a new, more comprehensive approach to education, which is capable of forming and maintaining a number of principles and human rights for effective learning. At the same time, sports, understood broadly, may attract more and more various categories of spectators. This feature has made it the main component in tourist flow management, which can revive a whole city (territory) through sport events, such as the World Cup.

Besides, now sport may develop in compliance with the new global social and economic demands to become a resource into which it might be expedient to invest to provide sustainable socio-economic development long-term. 


\section{Acknowledgment}

The article was prepared with the financial support of Kazan Innovative University named after V. G. Timiryasov.

\section{References}

1. R. Light, M.A. Dixon, Contemporary developments in sport pedagogy and their implications for sport management education, Sport Management Review, 10 (2), 159175 (2007). Access mode: https://doi.org/10.1016/S1441-3523(07)70009-8

2. G. Altavilla, D. Tafuri, G. Raiola, Some aspects on teaching and learning by physical activity, Sport Science, 7 (1), 7-9 (2014)

3. B. Houlihan, D. Malcolm, Sport and society: a student introduction, Sage (2015) Access mode: http://dx.doi.org/10.4135/9781446278833

4. T. D'Isanto, P.A. Di Tore, Physical activity and social inclusion at school: A paradigm change, Journal of Physical Education and Sport, 16, 1099-1102 (2016)

5. N.L. Holt, Positive youth development through sport. Routledge (2016). Access mode: https://doi.org/10.4324/9781315709499

6. H.J. Gibson, Sport Tourism: a Critical Analysis for Research, Sport Management Review, 1, 45-76 (1998)

7. H.J. Gibson, Sport Tourism at a Crossroad? Considerations for the future, S. Gammon, J. Kurtzman (a cura di), Sport Tourism: principles and practice, 76, 111-128 (2002)

8. C. Pigeassou, Sport Tourism, a Growing Sector: Issues and Perspectives in France, S. Gammon, J. Kurtzman (a cura di), Sport tourism: principles and practice, 76, 129-140 (2002)

9. E.V. Zarova, I.V. Solntsev, Econometric models in studying the impact of sport industry on the socio-economic development of a region (by the example of the Republic of Mordovia), Bulletin of the Plekhanov Russian University of Economics, 4 (88), 131-144 (2016)

10. C. Gratton, P. Taylor, Economics of Sport and Recreation, London and New York: Spon Press (2000). Access mode: https://doi.org/10.4324/9780203474839

11. M. Leeds, P. Von Allmen, The economics of sports, Boston: Addison Wesley (2002). Access mode: https://doi.org/10.1002/mde.1043

12. Study on the Contribution of Sport to Economic Growth and Employment in the EU. Study commissioned by the European Commission, Directorate-General Education and Culture. Final Report (2012)

13. E. Uslaner, Democracy and Social Capital, Democracy and Trust, 121-150 (1999). Access mode: https://doi.org/10.1017/CBO9780511659959

14. M. Warren, Democracy and Association. Princeton, NJ: Princeton University Press (2001). Access mode: https://doi.org/10.1007/s11577-002-0051-8

15. R.D. Putnam, Bowling alone: America's declining social capital, Journal of democracy, 6 (1), 65-78 (1995)

16. G. Papp, G. Prisztoka, Sportsmanship as an Ethical Value, International Review for Sociology of Sport, 30, 375-389 (1995). Access mode: https://doi.org/10.1177/101269029503000309 
17. R. Gough, Character Is Everything. Fort Worth, TX: Harcourt Brace College Publishers (1997). Access mode: $\underline{\text { https://doi.org/10.1177/1356336X9800400207 }}$

18. N. Elias, The Genesis of Sport as a Sociological Problem, The Sociology of Sport, 88115 (1971). Access mode: https://doi.org/10.1111/j.1467-954X.1985.tb03302.x

19. R. Mandell, Sport. A Cultural History (1984)

20. M. Levi, Social and Unsocial Capital: A Review Essay of Robert Putnam's Making Democracy Work, Politics \& Society, 24, 45-55 (1996). Access mode: https://doi.org/10.1177/0032329296024001005

21. D. Stolle, 'Getting to Trust': An Analysis of the Importance of Institutions, Families, Personal Experiences and Group Membership', Social Capital and Participation in Everyday Life, 118-133 (2001)

22. D. Stolle, The Sources of Social Capital, Generating Social Capital, 19-42 (2003)

23. J. Johnson, Conceptual Problems as Obstacles to Progress in Political Science, Journal of Theoretical Politics, 15, 87-115 (2003). Access mode: https://doi.org/10.1177/0951692803151004

24. Ø. Seippel, Sport and social capital, Actasociologica, 49 (2), 169-183 (2006). Access mode: https://doi.org/10.1177/0001699306064771

25. N. Lin, Social Capital (2001). Access mode: https://doi.org/10.1017/CBO9780511815447

26. J. Hargreaves, Sport, Power and Culture (1986). Access mode: https://doi.org/10.1111/j.1467-954X.1985.tb03304.x

27. C. Lasch, The Culture of Narcissism (1991). Access mode: https://doi.org/10.1177/004057368003600413

28. R. Gruneau, The Critique of Sport in Modernity: Theorizing Power, Culture, and the Politics of the Body, The Sports Process, 85-109 (1993). Access mode: https://doi.org/10.1177/0193723505276228

29. W. Morgan, Leftist Theories of Sport (1994). Access mode: https://doi.org/10.1080/00948705.1995.9714520

30. T. Tännsjö, C. Tamburrini (eds.), Values in Sport (2000). Access mode: https://doi.org/10.4324/9780203184691

31. M. Cameron, C.J. MacDougall, Crime prevention through sport and physical activity, 165 (2000). Access mode: https://doi.org/10.5937/zrpfni1569133D

32. G. Nichols, Sport and crime reduction: The role of sports in tackling youth crime. Routledge (2010). Access mode: https://doi.org/10.1111/j.1468-2311.2008.00543_3.x.

33. D. Ekholm, Sport and crime prevention: Individuality and transferability in research, Journal of sport for development, 1(2) (2013). Access mode: https://doi.org/10.1080/09627259608552727

34. D. Di Palma, G. Raiola, D. Tafuri, The strategic contribution of sport to the management of diversity, Sport Science, 10 (1), 40-43 (2017)

35. D. Di Palma, D. Tafuri, A. Ascione, G. Raiola, Social, Tourism and Educational development through Sport, Journal of Physical Education and Sport, 18, 473-478 (2018)

36. P. De Knop, J. Standeven, Sport tourism (1999)

37. H.J. Gibson, Sport Tourism: a Critical Analysis for Research, Sport Management Review, 1, 45-76 (1998) 
38. H.J. Gibson, Sport Tourism at a Crossroad? Considerations for the future, Sport Tourism: principles and practice, 76, 111-128 (2002)

39. C. Pigeassou, Sport Tourism, a Growing Sector: Issues and Perspectives in France, Sport tourism: principles and practice, 76, 129-140 (2002)

40. E. Tarfanelli, Sport e turismo: come fare business con il turismo sportive (2010)

41. D. Di Palma, L'impatto economic dello sport in Italia. Unarisorsasu cui investire per risollevarel'economia Italiana, Le nuove frontiere del business sportivo. Implicazioni economiche e manageriali, 53-106 (2014)

42. T. D'Isanto, G. Altavilla, D. Tafuri, Physical and sport activity and the relation to the eight key competences of the recommendation of the European Parliament and of the council, Sport Science, 10, 66-70 (2017)

43. D. Di Palma, D. Tafuri, Special needs and inclusion in sport management: a specific literature review, Sport Science, 9(2), 24-31 (2016)

44. D. Di Palma, G. Raiola, D. Tafuri, Disability and Sport Management: a systematic review of the literature, Journal of Physical Education and Sport, 16 (3), 785-793 (2016)

45. D. Di Palma, G. Raiola, D. Tafuri, The strategic contribution of sport to the management of diversity, Sport Science, 10 (1), 40-43 (2017)

46. G. Mari, Sport e educazione, PEDAGOGIA E VITA, 65 (3-4), 154-175 (2007)

47. G. Farinelli, Pedagogia dello sport ed educazione della persona, 3 (2005)

48. R. Light, M.A. Dixon, Contemporary developments in sport pedagogy and their implications for sport management education, Sport Management Review, 10(2), 159175 (2007). Access mode: https://doi.org/10.1016/S1441-3523(07)70009-8

49. D. Di Palma, D. Tafuri, A. Ascione, G. Raiola, Social, Tourism and Educational development through Sport, Journal of Physical Education and Sport, 18, 473-478 (2018)

50. G. Raiola et al., Analysis on some aspects of the service in volleyball, Sport Science, 9 (1), 74-77 (2016)

51. G. Raiola, Motor learning and teaching method, Journal of Physical Education and Sport, 17, 2239-2243 (2017)

52. G. Altavilla, D. Tafuri, G. Raiola, Some aspects on teaching and learning by physical activity, Sport Science, 7 (1), 7-9 (2014)

53. E. Isidori, Filosofia dell'educazione sportiva: dalla teoria alla prassi (2012)

54. E. Isidori, A. Fraile, Educazione, sport e valori. Un approccio critico-riflessivo (2008)

55. T. D'Isanto, P.A. Di Tore, Physical activity and social inclusion at school: a paradigm change, Journal of Physical Education and Sport, 16, 1099-1102 (2016)

56. G. Raiola, D. Tafuri, Teaching method of physical education and sports by prescriptive or heuristic learning, Journal of Human Sport and Exercise, 10 (1), 377-384 (2015)

57. Y.U. Zhong-gan, "Combination of Sport and Education" Scrutinized from Field of Vision of Scientific Development Outlook, Journal of Shanghai Physical Education Institute, 5 (2005) 